\title{
Sensitivity of natural vegetation to climate change in the Euro-Mediterranean area
}

\author{
A. Anav ${ }^{1,3, *}$, A. Mariotti ${ }^{1,2}$ \\ ${ }^{1}$ Italian National Agency for New Technologies, Energy and Sustainable Economic Development (ENEA), 00196 Rome, Italy \\ ${ }^{2}$ Earth System Science Interdisciplinary Center, University of Maryland, College Park, Maryland 20740, USA \\ ${ }^{3}$ Present Address: Laboratoire de Météorologie Dynamique, IPSL, Ecole Polytechnique 91128, Palaiseau Cedex, France
}

\begin{abstract}
This study explores the sensitivity to future climate change of natural vegetation patterns in the Euro-Mediterranean area under the IPCC-A1B emission scenario, using a dynamic vegetation model forced by fully coupled high resolution regional ocean-atmosphere model simulations. Our results indicate that a future warmer climate could not only affect the regional terrestrial carbon cycle, but also significantly impact vegetation dynamics. Specifically, by 2021-2050, temperate deciduous vegetation is projected to replace boreal and grass vegetation in parts of northeastern Europe, while in North Africa, simulations show a progressive desertification. The changes in dominant vegetation are mainly related to the increased drought stress on vegetation and the enhanced fire frequency. As for the carbon cycle, large increases in net primary production (NPP) are found in northern Europe resulting from higher temperature and precipitation, as well as higher atmospheric $\mathrm{CO}_{2}$ levels. In contrast, smaller NPP increases are found in the Mediterranean region, where reduced precipitation and increased temperature leads to an increase in drought years and, hence, waterstress for vegetation.
\end{abstract}

KEY WORDS: Climate change $\cdot$ Vegetation cover change $\cdot$ Terrestrial carbon cycle $\cdot$ Regional climate model Resale or republication not permitted without written consent of the publisher

\section{INTRODUCTION}

Climate change resulting from fossil fuel emissions may significantly alter the terrestrial carbon cycle (in particular the capacity of soils and vegetation to store/release carbon), as well as the vegetation dynamics (e.g. Notaro et al. 2007, Sitch et al. 2008).

Some studies suggest that during the past several decades the boreal forests in northeastern Europe have experienced greening and an increase in photosynthetic activity (Tucker et al. 2001, Devi et al. 2008, Qian et al. 2010) resulting from increased surface temperature (Nakicenovic et al. 2000). The increase in photosynthetic activity may lead to a higher amount of carbon stored in vegetation and soil biomass.

On the other hand, the terrestrial ecosystems lose carbon primarily through respiration (autotrophic and heterotrophic; Valentini et al. 2000). Owing to rising temperatures, the metabolism of soil microbes is enhanced, and the decomposition of soil organic matter (SOM) is accelerated. This leads to an increase of soil organic carbon (SOC) release to the atmosphere (Davidson \& Janssens 2006).

In the future, the balance of carbon uptake by vegetation and carbon release from the soil due to climate warming will determine whether a given area will become a source or sink of carbon.

Process-based models, forced by general circulation models (GCMs), have been widely used to study the role of the terrestrial biosphere in the global carbon cycle and to assess changes in biogeochemical cycles associated with a changing climate (Cramer et al. 2001, Schaphoff et al. 2006, Morales et al. 2007, Notaro et al. 2007, Sitch et al. 2008). However, process-based models are highly sensitive to fine-scale climate variations, especially in regions of complex topography and sur- 
face cover, and in areas with strong maritime influence. Therefore, if there is a need to assess the carbon cycle and the vegetation dynamics at a regional scale, then the coarse resolution of GCMs (typically 100 to $200 \mathrm{~km}$ in latitude) is a serious limitation to further analysis (O'Brien et al. 2004, Morales et al. 2007). Regional climate models (RCMs) provide an increase in resolution and can capture physical processes and feedbacks occurring at the regional scale (Giorgi \& Mearns 1991). Consequently, process-based models, when forced by RCMs, can also capture physical and ecological processes at finer resolution, such as those associated to the local to regional scale carbon cycle, including changes in vegetation patterns and in carbon fluxes and storage (Morales et al. 2007).

Vegetation cover has changed markedly over the last few centuries, particularly over Europe, mainly due to agricultural activities (Reale \& Shukla 2000). Analysis of an ensemble of models has shown that the Mediterranean is one of the most responsive regions to climate change (Giorgi 2006) because of pronounced warming and a large decline in precipitation during the spring and summer seasons (Giorgi \& Bi 2005). More changes can therefore be expected over this century as a consequence of human activities and a warming climate. For example, Sheffield \& Wood (2008) projected an increase in the occurrence of drought over the 21st century, which will affect vegetation. Gao \& Giorgi (2008) found that by the end of this century, the southern Mediterranean region will experience a substantial increase and northward extension of arid regime lands, especially in areas such as the Iberian, Italian, Hellenic and Turkish peninsulas and areas of southeastern Europe (e.g. Romania and Bulgaria). Aridity will also increase in the northern African and Middle East coastal regions as well as in the major islands of the Mediterranean (Corsica, Sardinia and Sicily, Gao \& Giorgi 2008).

Drought occurrence and increasing aridity could have positive feedbacks on climate warming from natural deforestation (Cox et al. 2000, Gullison et al. 2007). Regional vegetation changes may in turn have a considerable influence on regional climate (Reale \& Shukla 2000, Heck et al. 2001, Sanchez et al. 2007) and include changes in the radiation budget via modifications in surface albedo, and changes in the hydrological cycle mainly in terms of evapotranspiration, precipitation and runoff (Findell et al. 2007). Dumenil-Gates \& Ließ (2001) found a slight cooling at the surface (1 K) related to the increased surface albedo that in turn reduces the input from net solar radiation at the surface, and reduced precipitation during the summer as a result of decreased evapotranspiration of plants in a deforestation experiment. Land cover changes also have had a high impact on the frequency of heat waves. Anav et al. (2010a) found for the Mediterranean region that deforestation decreases the number of summer hot days, while the afforestation increases the number of summer hot days.

There also exist previous attempts to study and quantify the effects of climate change on the terrestrial carbon cycle and vegetation dynamics for Europe. However, the coarse resolution of the input climatic data used in some of these experiments limited the ability of the models to capture local phenomena occurring in regions with complex topography. For example, Zaehle et al. (2007) forced the LPJ dynamic vegetation model (Sitch et al. 2003) with the output provided by 4 GCMs. In contrast, Morales et al. (2007) forced the LPJ-GUESS model with the output of RCM downscaling experiments conducted within the EU project PRUDENCE (Christensen \& Christensen 2007). Zaehle et al. (2007) and Morales et al. (2007) found that European terrestrial ecosystem NPP will markedly increase under climate change. Morales et al. (2007) also found contrasting ecosystem impacts between southern and northern areas of Europe. In southern Europe, ecosystem impacts were dominated by the effects of increasing growing season water deficits, whereas impacts in northern Europe were dominated by changes in the duration of the growing season and the efficiency of carbon assimilation.

In this study, we focus specifically on how natural vegetation cover in the Euro-Mediterranean region may change as a result of future climate change, and discuss key underlying mechanisms. Unlike previous regional experiments for Europe (e.g. Morales et al. 2007, Zaehle et al. 2007), we employ simulation outputs from a high-resolution fully coupled oceanatmosphere RCM model to force the LPJ dynamic vegetation model and analyze future changes in regional carbon cycle and patterns of dominant vegetation in relation to past mean conditions.

We mainly focus on the processes that may intervene as regional climate changes in the Euro-Mediterranean area, while sensitivity of the results to model resolution or emission scenarios is beyond the scope of this study.

\section{MODELS AND EXPERIMENTS}

\subsection{PROTHEUS system}

The climate simulations used to force the LPJ vegetation model are from the PROTHEUS system, a regional coupled model for climate studies over the Mediterranean region (Artale et al. 2009). In this system the RegCM3 atmospheric regional model (Pal et al. 2007 and references therein), and the MITgcm 
oceanic model (Marshall et al. 1997a,b) are coupled through the OASIS3 coupler. A detailed description of the features and performance of PROTHEUS can be found in Artale et al. (2009).

RegCM3 is a limited-area model initially developed by Giorgi et al. (1990, 1993a,b), and modified by Giorgi \& Mearns (1999) and Pal et al. (2000, 2007). The model is compressible, based on primitive equations, and employs a terrain-following $\sigma$-vertical coordinate. The physical exchanges between the land surface and the boundary layer are simulated in RegCM3 by the hydrological process model Biosphere-Atmosphere Transfer Scheme (BATS) (Dickinson et al. 1993). Vegetation dynamics are not explicitly modeled in this RegCM version (or configuration).

The model domain in the PROTHEUS system is centered on Italy at $41^{\circ} \mathrm{N}$ and $15^{\circ} \mathrm{W}$, and is projected on a Lambert conformal grid covering Europe (except northern Scandinavia and Iceland) and North Africa (Fig. 1); the domain covers $160 \times 150$ grid points in the longitudinal and latitudinal directions, respectively, with an horizontal resolution of $30 \mathrm{~km}$.
Lateral boundary conditions, required to run the model, are supplied by interpolating the horizontal velocity, temperature, specific humidity and surface pressure onto the model grid and by relaxing the prognostic model variables for a 12-grid-point-wide lateral buffer zone with an exponentially decreasing coefficient (Giorgi et al. 1993b). In its standard configuration, at the air-sea interface, RegCM3 reads the sea surface temperature (SST) from boundary condition input files. This procedure is maintained in the coupled configuration. However, in the present study the MITgcm oceanic model (the ocean component of the PROTHEUS system, developed by Marshall et al. $1997 \mathrm{a}, \mathrm{b})$ supplies the SST field to RegCM3, as described in Artale et al. (2009).

In the present study the MITgcm is used in its hydrostatic, implicit free-surface, partial step topography formulation (Adcroft et al. 1997). The model is forced at the surface through the specification of wind stress and heat fluxes taken from the RegCM3 (Artale et al. 2009). The model domain covers the whole Mediterranean basin and extends out of the Strait of Gibraltar; the

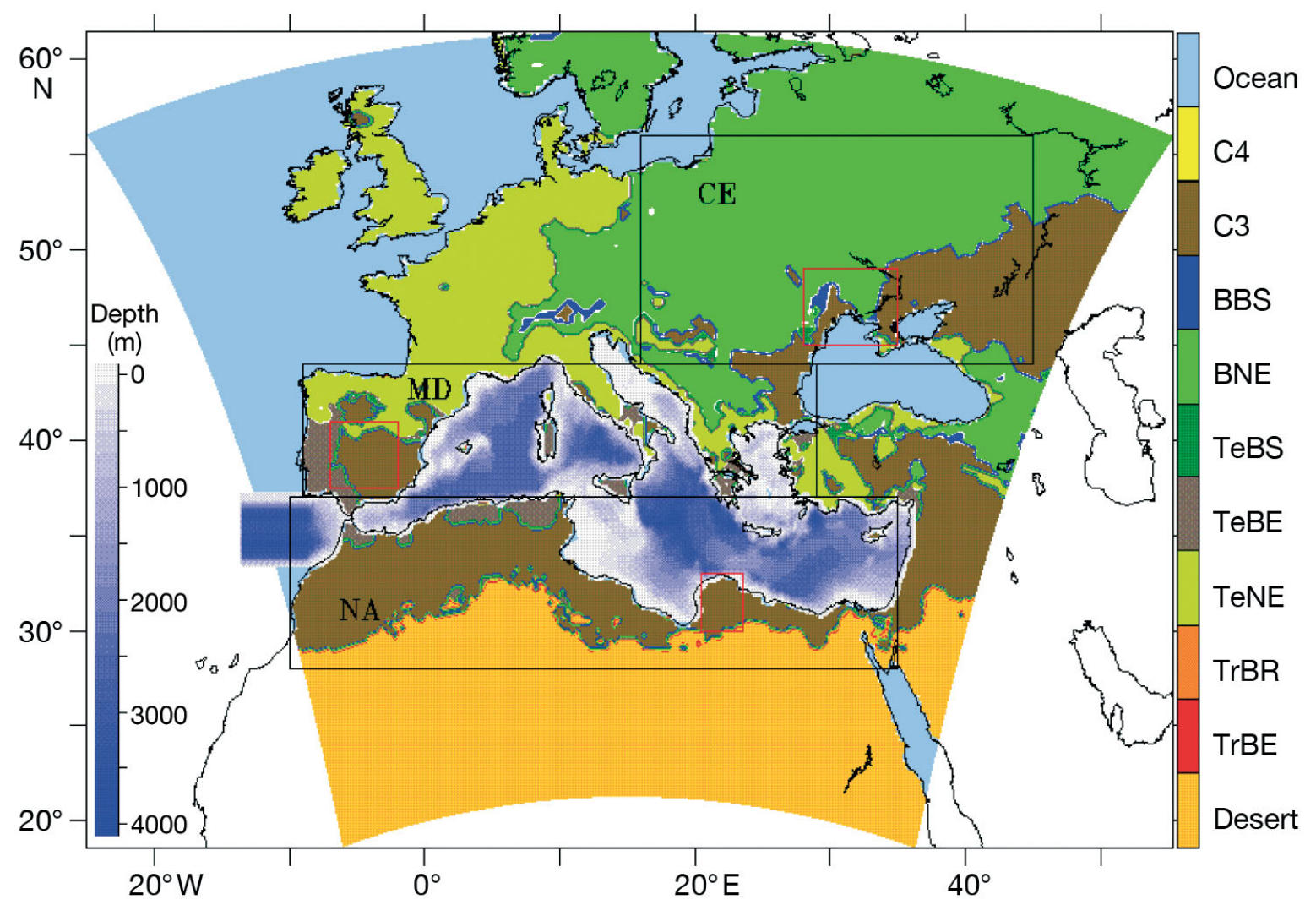

Fig. 1. PROTHEUS domain with the corresponding dominant vegetation simulated by LPJ in the period 1961-1990, and bathymetry from the MIT general circulation model (MITgcm; units are in meters). Black boxes: sub-domains where model diagnostics have been computed - NA: North Africa $\left(10^{\circ} \mathrm{W}-35^{\circ} \mathrm{E}, 28^{\circ} \mathrm{N}-37^{\circ} \mathrm{N}\right)$; MD: Mediterranean $\left(9^{\circ} \mathrm{W}-29^{\circ} \mathrm{E}, 37^{\circ} \mathrm{N}-44^{\circ} \mathrm{N}\right)$; CE: Central Europe $\left(16^{\circ} \mathrm{E}-45^{\circ} \mathrm{E}, 44^{\circ} \mathrm{N}-56^{\circ} \mathrm{N}\right)$. Inside each sub-domain, smaller focus regions are also identified (NA-S, MD-S, and CE-S, according to the respective region). LPJ simulated plant functional types - TrBE: tropical broad-leaved evergreen; TrBR: tropical broad-leaved raingreen; TeNE: temperate needle-leaved evergreen; TeBE: temperate broad-leaved evergreen; TeBS: temperate broad-leaved summergreen; BNE: boreal needle-leaved evergreen; BBS: boreal broad-leaved summergreen; C3, C4: grasses (C3, C4 pathways) 
MITgcm domain and bathymetry are shown in Fig. 1 overlapped to the RegCM3 domain. Coupling fields are exchanged every $6 \mathrm{~h}$, which is the same frequency at which lateral boundary conditions are read in the atmospheric model. In the PROTHEUS simulations, the MITgcm transfers SST to the atmospheric model, while RegCM3 transfers to the ocean model wind stress, sensible heat flux, latent heat flux, long and short wave incident radiation at the surface (Artale et al. 2009).

\subsection{LPJ Dynamic Global Vegetation Model}

The LPJ-DGVM (Sitch et al. 2003) is a process-based model representing key ecosystem processes governing terrestrial biogeochemistry and biogeography. LPJ simulates the water and carbon exchanges between biosphere and atmosphere by means of a given set of parameters and climatic input variables. For each grid cell, vegetation is described in terms of the fractional percentage coverage (FPC) of 9 different plant functional types (PFTs) that are able to compete for space and resources (Sitch et al. 2003). Seven PTFs are woody -3 temperate, 2 tropical and 2 boreal-and two are herbaceous; the PFTs have different photosynthetic (C3, C4), phenological (deciduous, evergreen), and physiognomic (tree, grass) attributes (Sitch et al. 2003). The PFTs may in principle co-exist at any location, depending on plant competition and a set of environmental constraints. Their relative proportion is determined by competition among types with typical ecological strategies for dealing with temperature, water and light stress, and disturbances as well. Dispersal processes are not explicitly modeled, and an individual PFT can invade new regions if its bioclimatic limits and competition with other PFTs allow establishment.

Fire is the most important natural disturbance at a global scale, and is the only form of disturbance explicitly represented in LPJ (Sitch et al. 2003). A full description of the fire module is given by Thonicke et al. (2008), while a detailed evaluation of fire predictions against observations is described in Thonicke et al. (2010). In LPJ, fire occurrence is taken to be dependent upon fuel load (i.e. the amount of dry combustible material) and litter moisture, hence this formulation combines both the influence of climate and vegetation.

To start a fire, the fuel has to reach a minimum temperature at which it ignites. Combustion will start if there is sufficient fuel present at the grid cell. If moisture is above a certain level, then all available energy in the preheating process is consumed to vaporize water, thus ignition temperature is not reached, and ignition, either spontaneously or due to fire spread, fails. The resulting fire effects on vegetation in the fractional area burnt are calculated for each PFT. The fraction of vegetation killed depends upon the prescribed PFT fire resistance, which represents the PFT survivorship during a fire (Sitch et al. 2003, Thonicke et al. 2008).

LPJ is extensively used and has been validated for terrestrial carbon (Sitch et al. 2003), water exchanges (Gerten et al. 2007), vegetation distribution and dynamics (Bonan et al. 2003, Sitch et al. 2003), and it has also been used for scenario simulations (Lucht et al. 2006, Schaphoff et al. 2006, Morales et al. 2007, Zaehle et al. 2007) forced by a coarse resolution input data.

In the original model version, the LPJ simulations are driven by monthly fields of mean temperature, precipitation and cloud cover provided from the climate research unit (CRU) monthly climate dataset on a $0.5^{\circ}$ $\times 0.5^{\circ}$ global grid (New et al. 2000). The monthly fields are linearly interpolated to obtain pseudo-daily values, directly used at daily time steps to simulate short term processes, such as photosynthesis, respiration and evapotranspiration.

In the present study a modified version of LPJ has been used in order to read the higher resolution $(30 \mathrm{~km})$ temperature, precipitation and cloud cover data supplied by the PROTHEUS system.

\subsection{Model simulations and methodology}

Two different climate simulations were performed with the PROTHEUS system for the $100 \mathrm{yr}$ period 19512050, using simulation results from the ECHAM5/MPIOM1 (Roeckner et al. 2003) coupled general circulation model (CGCM) as lateral boundary conditions. In the control simulation (CTL), the outputs of the ECHAM5/ MPI-OM1 20C3M experiment (Nakicenovic et al. 2000) are used to represent climate for the period 1951-2000. In a second experiment, we used global climate projections from the ECHAM5/MPI-OM1 CGCM, based on the A1B scenario from the Intergovernmental Panel on Climate Change Special Report on Emissions Scenario (IPCC SRES; IPCC 2001), to represent changes under a climate change scenario for the period 2001-2050.

The A1B scenario describes a future world of very rapid economic growth and global population that peaks in mid-century and then declines thereafter following a slowing of growth that occurs with the rapid introduction of new and more efficient technologies (Nakicenovic et al. 2000).

Results from the PROTHEUS/ECHAM5 system were then used to force the LPJ dynamic global vegetation model.

A typical simulation with LPJ starts from bare ground (no plant biomass present for each grid cell) and spins up for $1000 \mathrm{yr}$ until equilibrium is reached with respect to carbon pools and vegetation cover. 
Usually, during the spin up phase, the model is driven with an approximately constant climate. However, since fires in many regions occur only in drier years, repeating a single year's climate or even using a longterm climate average, can lead to anomalous results (Sitch et al. 2003). The spin up therefore requires the use of an interannually varying climate, with annualaverage temperatures, precipitation and cloudiness fluctuation about constant long-term means (Sitch et al. 2003).

In the simulations presented here, during the spin up phase, $30 \mathrm{yr}$ of varying climate from the period 1951-1981, as simulated by PROTHEUS, were repeated continuously with pre-industrial atmospheric $\mathrm{CO}_{2}$ concentrations. Starting from the equilibrium (year 1901), the model was driven until 1951 using observed atmospheric $\mathrm{CO}_{2}$ content. From 1951, two different simulations were performed forcing LPJ with PROTHEUS CTL and SRES results.

Climate change impacts on carbon and vegetation patterns are investigated by comparing key characteristics of the ecosystems during the reference period 1961-1990 with those of the future scenario over the period 2021-2050. The focus is on the chain of events that may intervene to modify regional vegetation as climate changes, and not on exploring the sensitivity of the results to scenario and model uncertainty, as we only consider one among the various IPCC emission scenarios, and only one particular CGCM/RCM model set-up. However, it is arguable that to some extent our approach considers these factors indirectly, since we compare projections using the PROTHEUS system with those from a larger ensemble of 15 models among those that participated in the Coupled Model Intercomparison Project Phase 3 (CMIP3, Meehl et al. 2007; more details on the ensemble of models used can be found in Mariotti et al. 2008).

We discuss our model results in the context of this larger ensemble as an indirect way to explore model uncertainties. The A1B emission scenario is intermediate among the different IPCC scenarios, so we also expect results to be intermediate. The inter-comparison between the PROTHEUS simulations and CMIP3 results is performed over 3 large sub-regions (namely North Africa, the Mediterranean and central-eastern Europe-NA, MD and CE respectively; see Fig. 1), which correspond to the areas where the main changes in terms of dominant vegetation types are found. In each of these 3 sub-regions, we also consider a smaller domain (see Fig. 1) in order to highlight the factors driving regional vegetation dynamics.

In most of the Euro-Mediterranean region, land use is anthropic, with land cover distribution including both crops and farms. Hence vegetation change does not only depend on climate, but is also subject to eco- nomic and political changes. LPJ assumes that vegetation is natural everywhere and the change in land cover depends only on climate and disturbances (e.g. fires, competition among PFTs). This limits the realism of our study, since we do not refer to changes in the present observed vegetation, but rather in 'natural' vegetation cover (e.g. the state of vegetation cover in the absence of anthropic land-use).

Compared to other reconstructions of potential natural vegetation for the present climate, our land cover (Fig. 1) matches well the results found in Zampieri \& Lionello (2010), who observed that potential natural vegetation over most of central Europe consists of deciduous broadleaf trees, with large patches of mixed wood-savanna vegetation appearing towards the north-east. Evergreen conifers dominate over eastern-Europe and Scandinavia. Shrubs and barren soil are located along the southern coasts of the Mediterranean. Grasslands occupy the interior of Anatolia, part of Iberia, and the northern coast of the Black Sea. Unlike Zampieri \& Lionello (2010), in western Europe the land cover in the present study is characterized by temperate needle-leaved evergreen (TeNE) forests, with temperate broad-leaved evergreen (TeBE) and crops in the Iberian Peninsula, while the eastern side of the domain is dominated by boreal needle-leaved evergreen (BNE) (Fig. 1). A similar land cover is found in Sitch et al. (2003), where they forced LPJ with CRU data. They found the same pattern of our TeBE cover in Iberian Peninsula, and the same area of Spain is covered by natural C3 grass, while central Europe is dominated by TeNE. Several local to regional differences in land cover with respect to Sitch et al. (2003) occur however in central-east Europe and along the Black sea coasts, where their land cover is dominated by temperate broadleaved summergreen forests. Finally on the coasts of northern Africa our land cover matches closely results from Sitch et al. (2003).

In order to see the differences in terms of vegetation cover due to different climate forcing provided during the spin up phase, and to better compare the PROTHEUS-based LPJ mean vegetation cover with CRU land cover, we also performed a simulation forcing LPJ with CRU data. In Fig. 2 we show the dominant vegetation cover at the beginning of the simulation (1961) using both PROTHEUS and CRU climatic forcing. Results show that both simulations give C3 grass as the dominant vegetation type in North Africa; central western Europe is dominated by temperate trees, while in central north Europe boreal trees are dominant. However, some differences exist, especially at the margins of areas of dominant vegetation types. Vegetation cover using CRU gives generally results closer to those of Sitch et al. 2003, namely along the Black Sea coasts where temperate deciduous forest are 

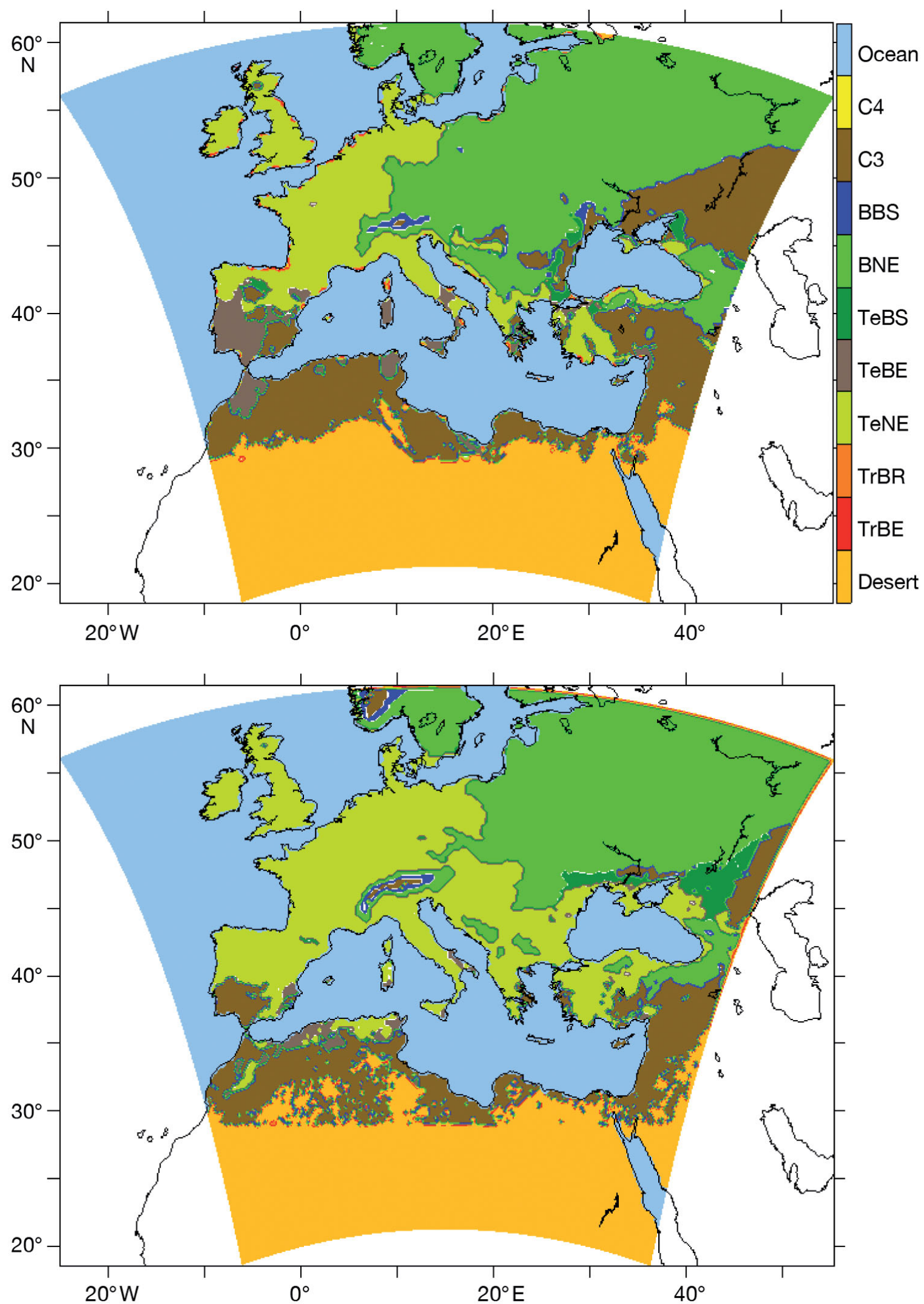

Fig. 2. Dominant vegetation cover at the beginning of the simulation (year 1961) as simulated by LPJ forced by PROTHEUS (upper panel) and Climate Research Unit (CRU) (lower panel). Abbreviations as in Fig. 1 
the dominant vegetation. However, the CRU-based LPJ vegetation cover is not exactly the same as that used by Sitch et al. (2003), since the temporal period during which the vegetation cover has been computed to be different between the 2 experiments.

The PROTHEUS climatological results agree reasonably well with CRU data at least for surface air temperature (discussed later). Since in LPJ temperature is the main variable that affects potential vegetation cover, a reasonable agreement between the PROTHEUSbased LPJ mean vegetation cover and that found by Sitch et al. (2003) using CRU data is to be expected. Along the Black sea coasts, however PROTHEUS has a strong positive bias in precipitation (discussed later), which can at least partially explain the discrepancies in terms of land cover found between PROTHEUS and CRU simulations. In contrast, more substantial differences in term of carbon cycle in the simulations using CRU and PROTHEUS climatic forcing are to be expected, as PROTHEUS systematically overestimates precipitation leading to more favorable conditions for plant growth (i.e. vegetation does not suffer severe water stress during summer).

Since the changes in carbon cycle and dominant vegetation are strictly related to the changes in temperature and precipitation, we limit our intercomparison to these climatic quantities and also analyze the Palmer drought severity index (PDSI; Palmer 1965) to synthesize their combined effect on soil moisture. Among various indices for drought detection, the PDSI is one of the most widely used. It is a meteorological drought index, and it responds to weather conditions that have been abnormally dry or abnormally wet. The PDSI is computed based on precipitation and temperature data. Negative PDSI values indicate dry conditions, while positive values indicate wet periods; values around zero denote near-average water balance. Extreme conditions take place when the PDSI is greater/less \pm 6 .

\section{RESULTS}

\subsection{Changes in surface climate}

Quantitative estimates of the model temperature and precipitation biases are shown in Fig. 3 and Fig. 4, respectively. In these figures, the seasonal means and standard deviations of the latter variables simulated by PROTHEUS are compared to the observed CRU data, the mean of an ensemble of CMIP3 models, and the ECHAM5 boundary condition used to force PROTHEUS.

The seasonal averages and standard deviations have been computed over the control period 1961-1990 for the 3 sub-domains of Fig. 1. In this regard, we can evaluate the capability of the PROTHEUS system to reproduce the thermal structure in the near surface atmospheric levels and precipitation.

In general, temperatures averaged over the selected sub-regions for the present climate simulation are in good agreement with the CRU temperatures (Fig. 3). Specifically, in MAM and SON the results from PROTHEUS, ECHAM5 and CMIP3 do not show any significant differences compared to CRU. Larger differences occur in DJF (mainly in MD sub-region) and in JJA (in NA and CE), with CMIP3 being generally closer to observations, as expected by an ensemble
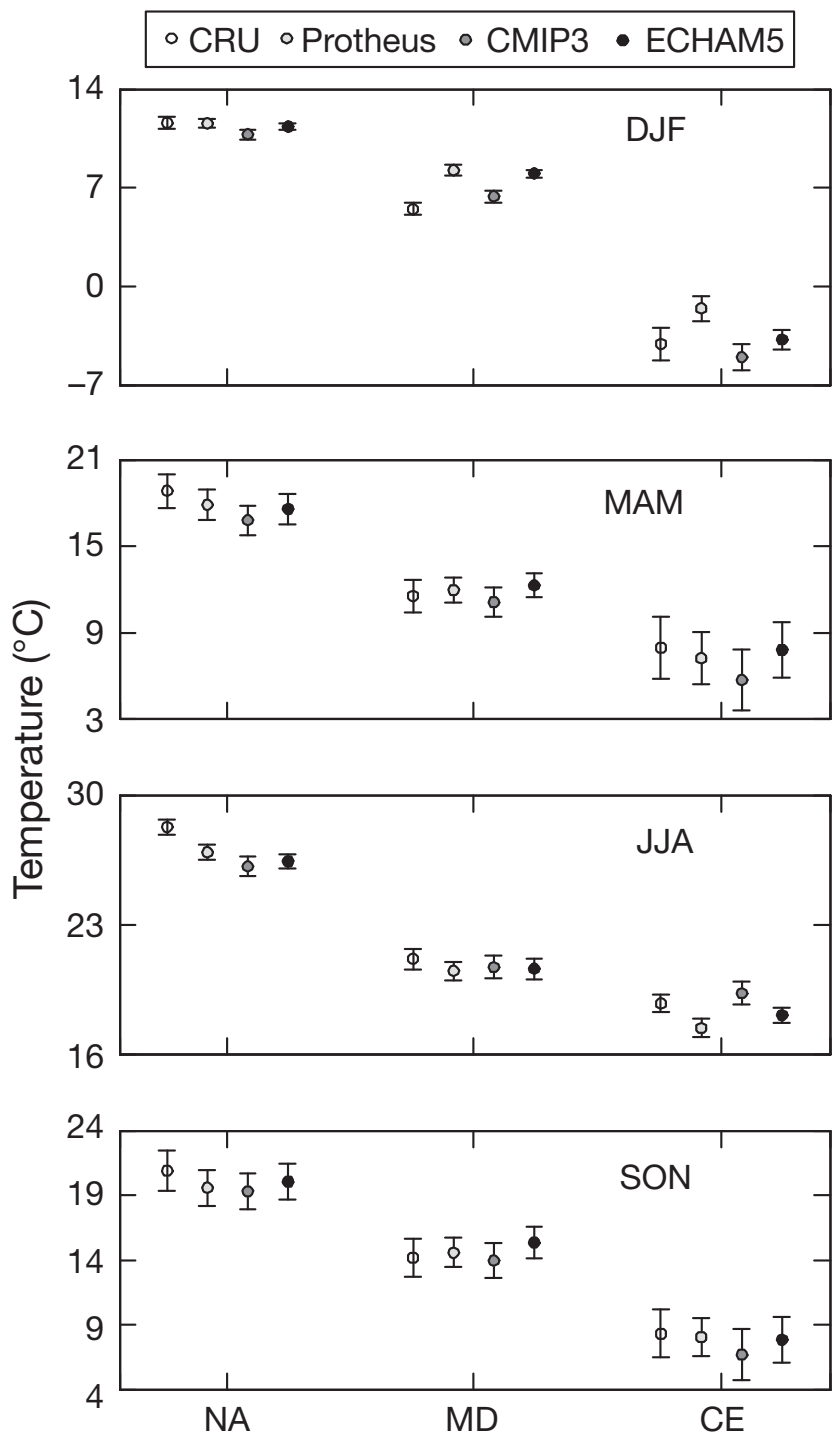

Fig. 3. Seasonal means (1961-1990) of observed CRU and simulated (PROTHEUS, ECHAM5 and CMIP3 models ensemble mean) $2 \mathrm{~m}$ temperature averaged over the 3 sub-regions (see Fig. 1 for abbreviations) with the associated standard deviations. DJF, MAM, JJA, SON: winter, spring, summer and autumn, respectively 

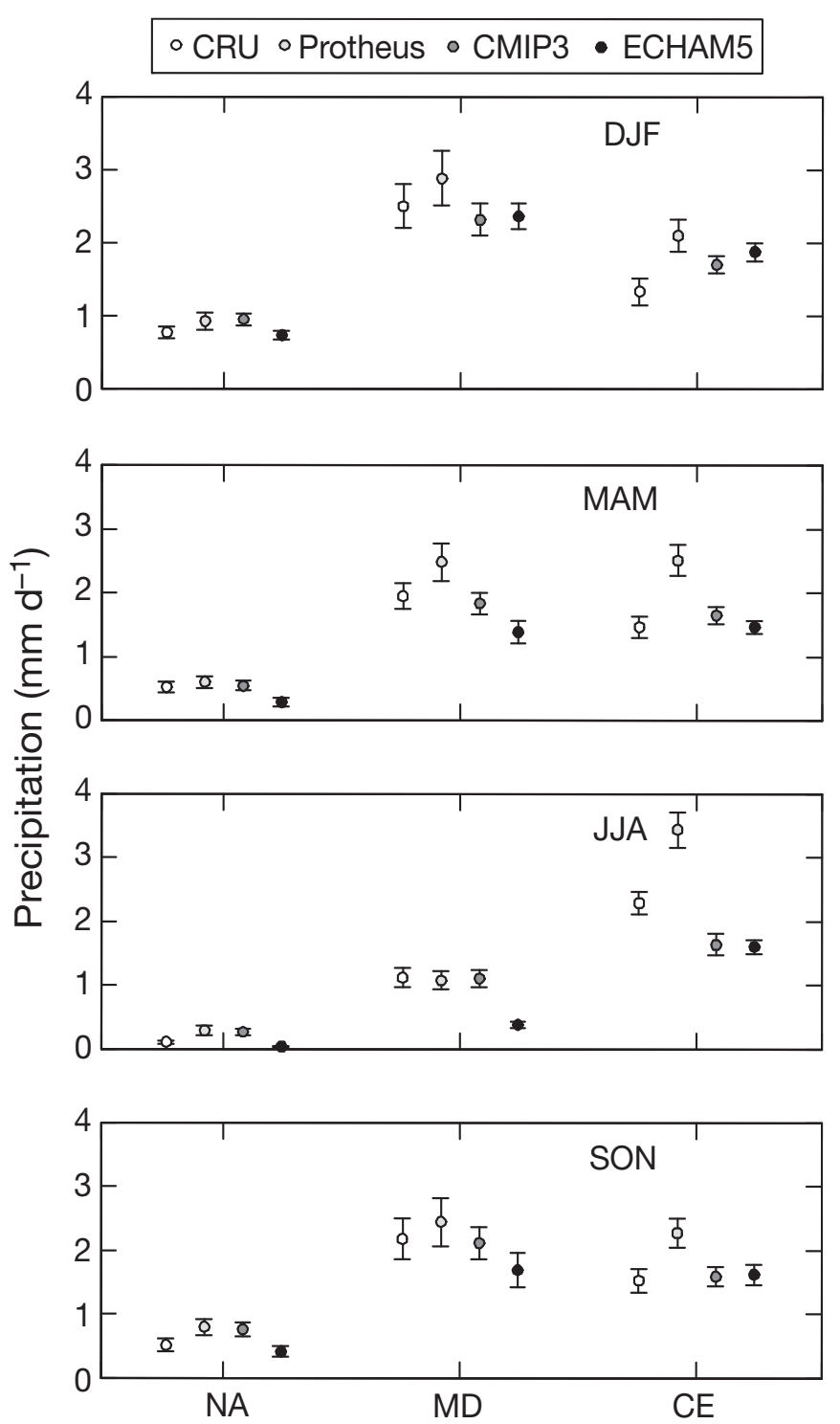

Fig. 4. Seasonal precipitation means. Other details as for Fig. 3

mean. Finally, during all seasons and in all sub domains PROTHEUS is close to its boundary conditions, and both PROTHEUS and ECHAM5 show the same bias with respect to CRU. This suggests that the downscaling does not significantly improve model simulation of mean surface temperature, at least on these sub domains (the impact on other aspects of simulated climate, such as extremes, has not been explored here).

PROTHEUS systematically overestimates precipitation in all the sub-regions, except in NA where generally it is dry year-round (precipitation $<1 \mathrm{~mm} \mathrm{~d}^{-1}$; see Fig. 4). The overestimation of precipitation occurs both in the stand-alone and in the coupled version of the RCM (described in Giorgi et al. 2004 and Artale et al. 2009, respectively). The effects of this strong bias on vegetation are described in Anav et al. (2010b). The most severe PROTHEUS bias occurs in the CE subregion, where precipitation is higher during all seasons, while ECHAM5 and CMIP3 generally match the observations (the latter is closest to CRU, as to be expected from an ensemble mean).

It is noteworthy that only ECHAM5 temperature is used as lateral boundary condition to force RegCM3, while precipitation is diagnostically computed by PROTHEUS.

The temporal evolution over the period 1961-2050 of surface air-temperature, precipitation and PDSI anomalies, as depicted by PROTHEUS, ECHAM5 and the CMIP3 ensemble, is shown in Fig. 5. PROTHEUS generally shows a positive trend in surface temperature in all sub-regions. A marked increase occurs in NA $\left(0.22^{\circ} \mathrm{C}\right.$ decade $\left.^{-1}\right)$ while in $\mathrm{CE}$ and $\mathrm{MD}$ regions the warming is slightly less pronounced $\left(0.18^{\circ} \mathrm{C}\right.$ decade $^{-1}$ and $0.20^{\circ} \mathrm{C}$ decade ${ }^{-1}$, respectively). Overall, the PROTHEUS-simulated warming is similar to that of the 15 models from the CMIP3 ensemble. However, in all sub-regions the warming projected by PROTHEUS is less than that of the CMIP3 ensemble mean $(0.27,0.26$, and $0.30^{\circ} \mathrm{C}$ decade $^{-1}$ over NA, MD and CE, respectively). The PROTHEUS simulated warming is consistent with that of ECHAM5 in NA $\left(0.24^{\circ} \mathrm{C}\right.$ decade $\left.^{-1}\right)$ and $\operatorname{MD}\left(0.23^{\circ} \mathrm{C}\right.$ decade $\left.{ }^{-1}\right)$, while the latter model shows a more pronounced trend in $\mathrm{CE}\left(0.31^{\circ} \mathrm{C}\right.$ decade $\left.^{-1}\right)$.

Considering precipitation, PROTHEUS results are generally similar to those from the CMIP3 ensemble, although PROTHEUS shows a larger interannual variability (PROTHEUS values fall outside the $\pm 1 \mathrm{SD}$ interval derived from the CMIP3 ensemble). Over the long term, PROTHEUS shows a decrease in precipitation over the NA and MD sub-regions (-0.056 and $-0.018 \mathrm{~mm} \mathrm{~d}^{-1}$ per decade, respectively), consistent with previous studies (Mariotti et al. 2008). In contrast, over CE, PROTHEUS simulates an increase in precipitation in the scenario experiment $\left(0.019 \mathrm{~mm} \mathrm{~d}^{-1}\right.$ per decade). In MD, the PROTHEUS precipitation trend is generally similar to ECHAM5 (-0.023 $\mathrm{mm} \mathrm{d}^{-1}$ per decade) and CMIP3 trends (-0.019 $\mathrm{mm} \mathrm{d}^{-1}$ per decade). Over NA, the decrease in precipitation is lower in ECHAM5 (-0.011 $\mathrm{mm} \mathrm{d}^{-1}$ per decade) and CMIP3 $\left(-0.015 \mathrm{~mm} \mathrm{~d}^{-1}\right.$ per decade) than in PROTHEUS. Finally, in CE the ECHAM5 (0.007 $\mathrm{mm} \mathrm{d}^{-1}$ per decade) and CMIP3 trends (0.006 $\mathrm{mm} \mathrm{d}^{-1}$ per decade) are lower than those projected by PROTHEUS. The difference in precipitation trends over CE between PROTHEUS and ECHAM5-CMIP3 is likely related to the systematic overestimation of precipitation by RegCM3 in this region (Fig. 4).

The PDSI projections, reflecting the combined effects of precipitation and surface temperature changes on soil moisture content, show significant changes over 

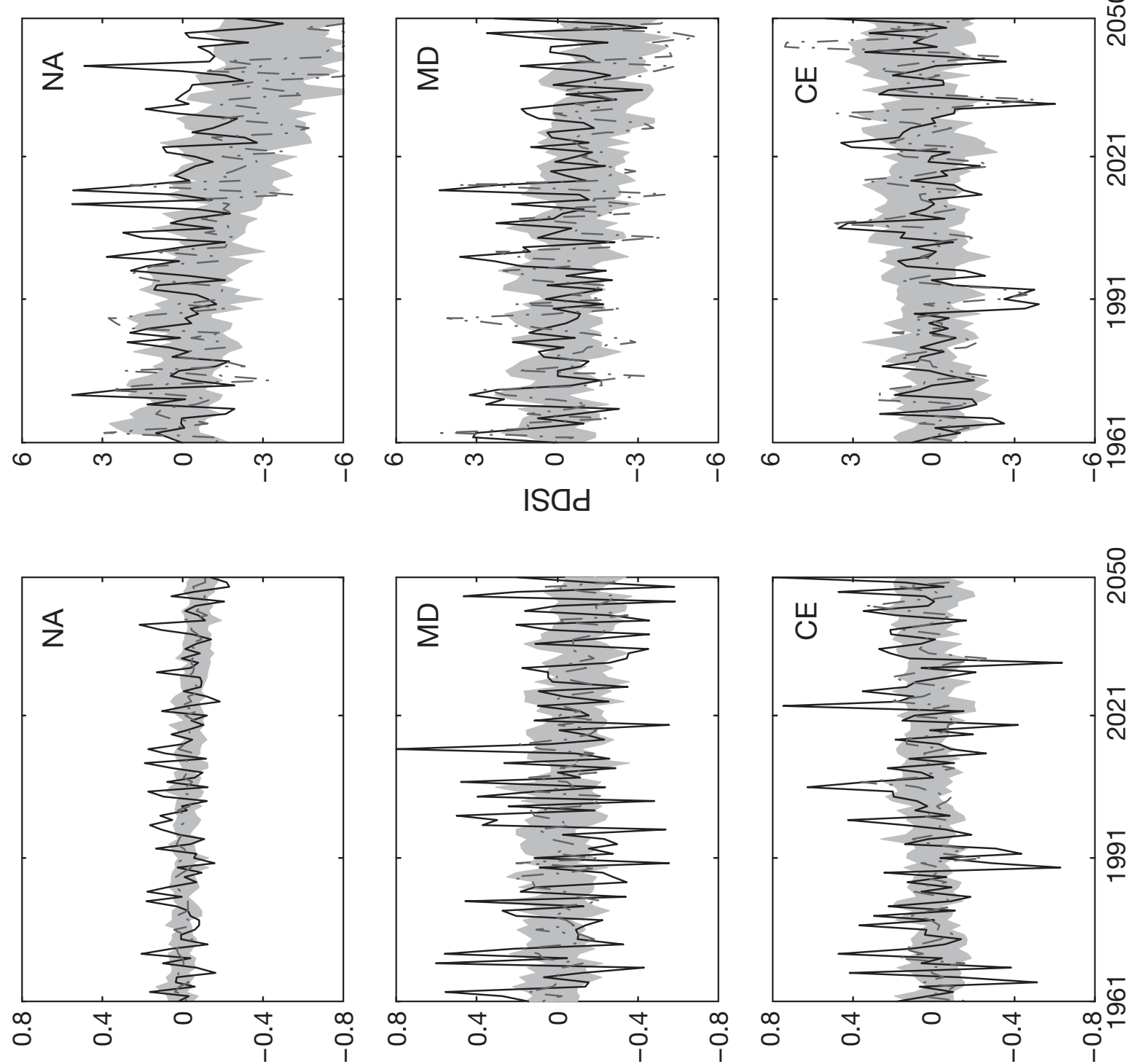

\section{(_-p um) uo!̣e!!}

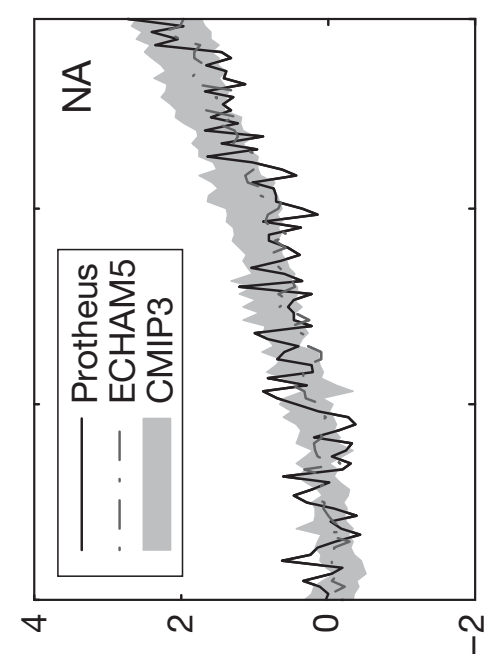

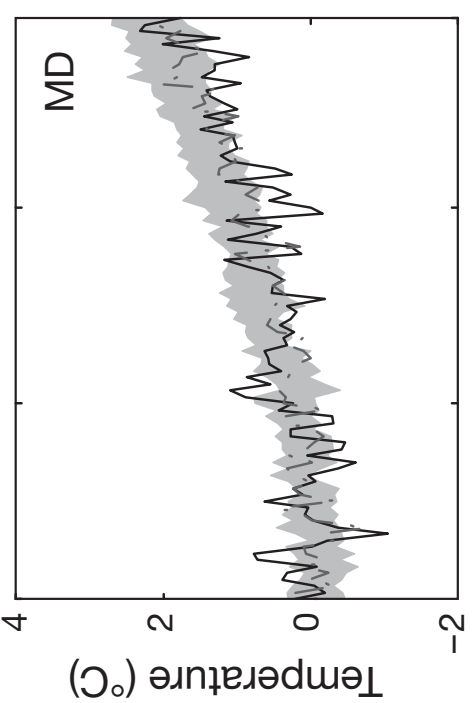

년

s. 0

릉

वี के :

จำ

च्ठ

묘 욤

表

实

욱 뭉

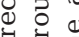

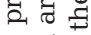

离胥

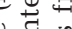

.

记

要

घ

\& : 중

的

की

is $\dot{\vec{f}}$

它

일

용

군

敋完

7.

롬

웡

\&

.

वे 웅

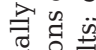

त्व

to

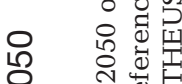

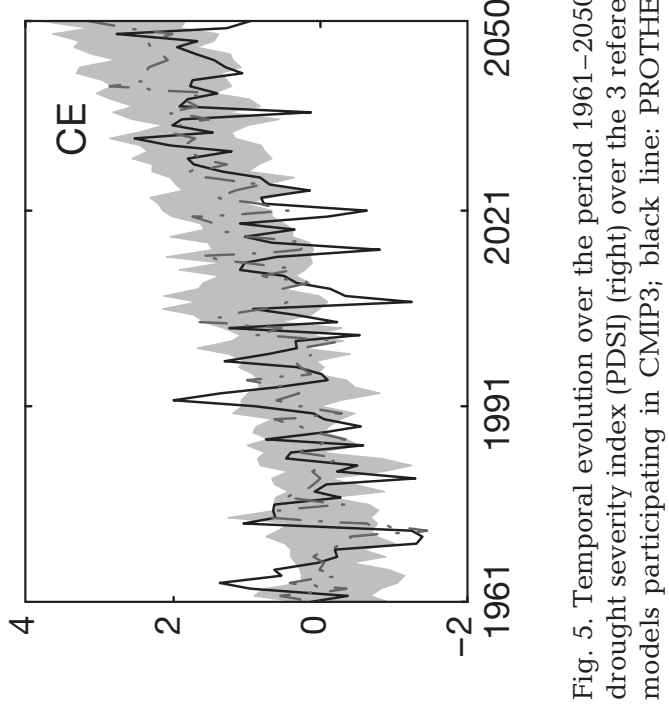



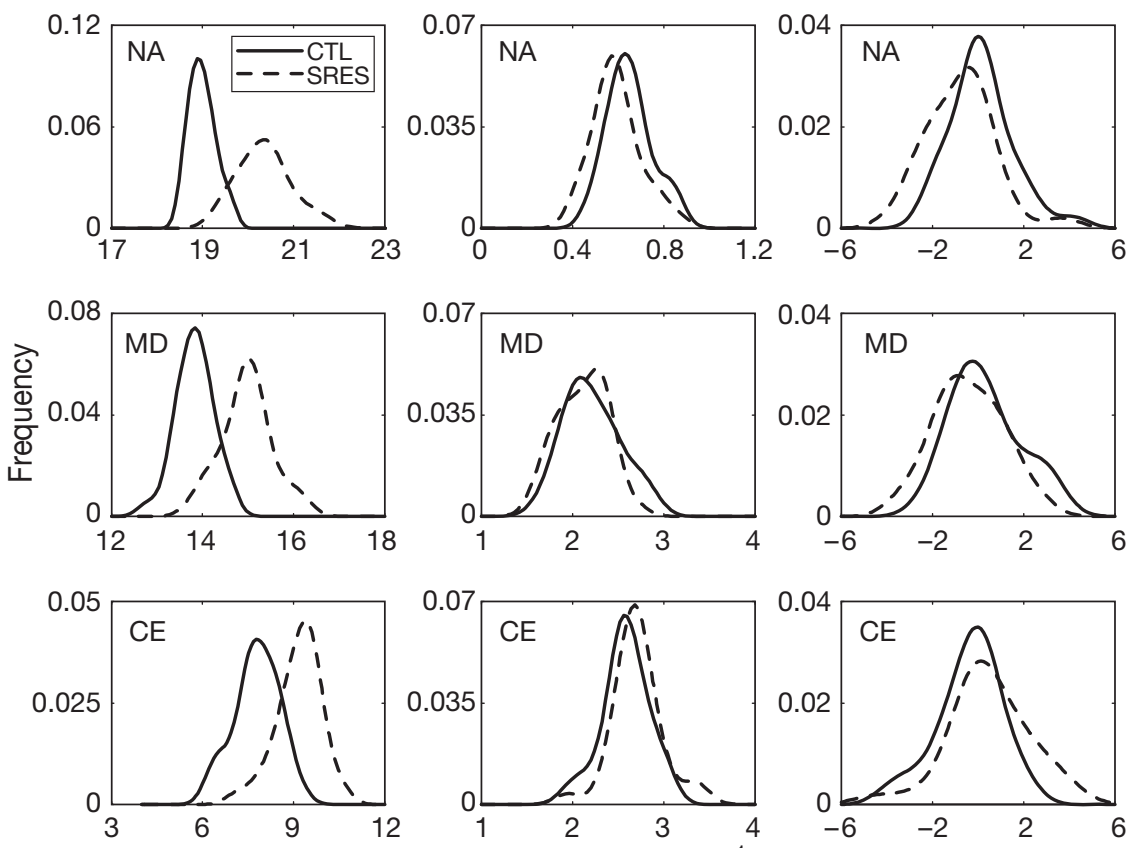

Surface air temperature $\left({ }^{\circ} \mathrm{C}\right.$
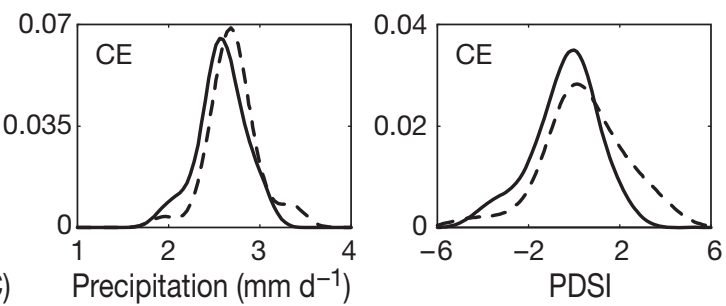

Fig. 6. Probability distribution of control (solid line), and scenario (dashed line), annual mean surface temperature, precipitation and PDSI as simulated by PROTHEUS. The probability density function has been spatially averaged over the 3 sub-domains (NA, MD, CE), shown in Fig. 1. The reference period for the control run is 1961-1990, while for the scenario it is 2021-2050

the Euro-Mediterranean region. These include a drying of the land surface simulated by PROTHEUS over the NA and MD regions ( -0.15 and -0.12 units decade $^{-1}$, respectively), consistent with a decrease in precipitation and an increase in air temperature over these regions, and a wetting over CE (0.14 units decade $^{-1}$ ) mainly owing to the increased precipitation. The drying found in the Mediterranean region based on PROTHEUS is consistent with previous analyses of global climate change projections over this region (Mariotti et al. 2008, Sheffield \& Wood 2008). It is noteworthy that PDSI drying trends over NA and MD are larger in ECHAM5 (-0.6 and -0.4 units decade ${ }^{-1}$, respectively) and CMIP3 (-0.4 and -0.2 units decade ${ }^{-1}$, respectively), than PROTHEUS. Instead, over $\mathrm{CE}$, the PDSI trends from both ECHAM5 (0.13 units decade ${ }^{-1}$ ) and CMIP3 ensemble mean (0.1 units decade ${ }^{-1}$ ) are close to the PROTHEUS' value.

Next, we consider changes in the mean and the variability of key climatic quantities spatially-averaged over the 3 reference sub-regions by analyzing probability density functions (PDF) of the PROTHEUS control for 1961-1990 and the scenario experiment for 2021-2050 (Fig. 6). Consistently with the anomalies shown in Fig. 5, changes in temperature PDFs indicate a significant warming in all sub-regions. The greatest warming occurs in NA, where by 2021-2050 mean temperature is increased by about $2{ }^{\circ} \mathrm{C}$ from the period 1961-1990. In the remaining sub-regions, the warming is slightly less than $2^{\circ} \mathrm{C}$. Unlike NA, in other regions the variance of the temperature PDF does not change between the control and the scenario simulations. On the other hand, the precipitation PDFs do not show any relevant changes in the mean values. However, a slight drying is observed in NA and MD as a shift toward lower values in the PDF tails, while in CE an increase of precipitation occurs.

\subsection{Change in vegetation dynamics and carbon cycle}

Climate change and increasing atmospheric $\mathrm{CO}_{2}$ concentration generally lead to a rise in NPP in all sub-regions (Fig. 7). As already highlighted by Schaphoff et al. (2006) for dry regions, the modest NPP increases found in NA and MD are due to the projected high temperatures and associated increase in water stress (as suggested by Fig. 5). This implies that the NPP is limited under drying soils in these 2 sub-regions, owing to higher temperature and slightly less precipitation.

The NPP PDF projections for CE show a significant increase of about $200 \mathrm{gC} \mathrm{m}^{2} \mathrm{y}^{-1}$ in the mean value, and a large increase of variance related to the interannual variability. The increase of the mean value is primarily the result of the physiological and phenological effects of higher temperatures and precipitation, and fertilization effects of increased $\mathrm{CO}_{2}$ levels (Gerber et al. 2004, Ainsworth \& Long 2005). Specifically, the increase in temperature leads to longer growing seasons, and enhanced precipitation does not induce any water-stress condition on vegetation so that more $\mathrm{CO}_{2}$ can diffuse into stomata, hence more carbon is stored in vegetation. Conversely, the increase in variance is related to the summer heat waves, and hence the drought effect on vegetation occurring during some years, as shown in Fig. 5 (negative peaks in PDSI).

The increased temperature and enhanced soil moisture stress provide favourable conditions for an increase in fire events. Fig. 7 also shows the amount of burned carbon in the reference regions as a measure of the occurrence of these fire events. The largest increase in carbon loss for fires are found in MD, while in NA and CE the increase is slightly lower. 

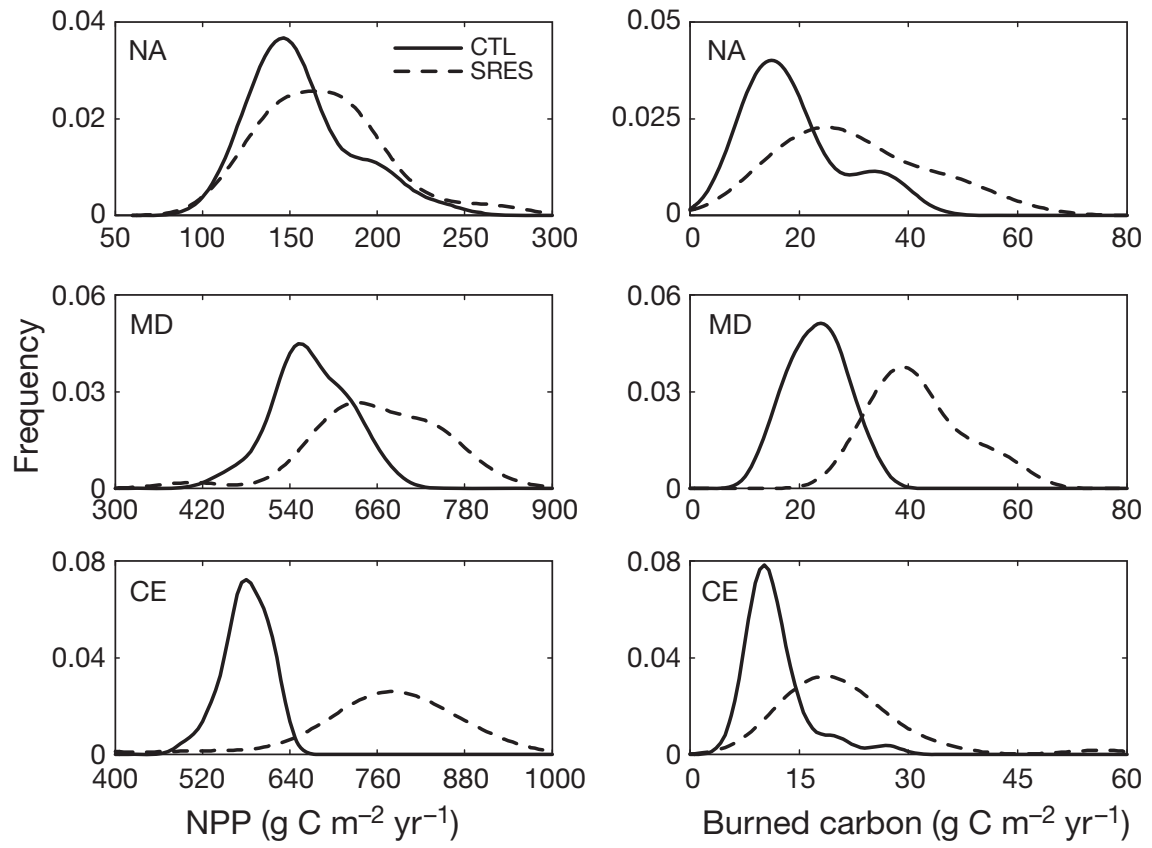

Fig. 7. Probability distribution of control (solid line), and scenario (dashed line), annual mean net primary production (NPP), and biomass burned carbon as simulated by LPJ. The probability density function have been spatially averaged over the 3 sub-domains shown in Fig. 1. The reference period for the control run is 1961-1990, while for the scenario it is 2021-2050
An important finding is that in the PROTHEUS-LPJ simulations, increased temperature is also associated with a shift in dominant vegetation patterns (Fig. 8), since new vegetations types are better suited to the changing climatic environment. Significant changes in terms of PFT are found in eastern Europe where BNE and grass PFT (C3) are substituted with temperate broadleaved summergreen vegetation (TeBS). The increase of temperate broad-leaved tree cover mainly depends on the increased temperature that favours the establishment of temperate species, since the new mean temperature falls into their bioclimatic range of survival. In fact, in LPJ each PFT is assigned bioclimatic limits which determine whether it can survive and/or regenerate under the climatic conditions prevailing in a particular grid cell at a particular time in the simulation (Sitch et al. 2003).

Significant shifts in vegetation cover are also found in parts of northern

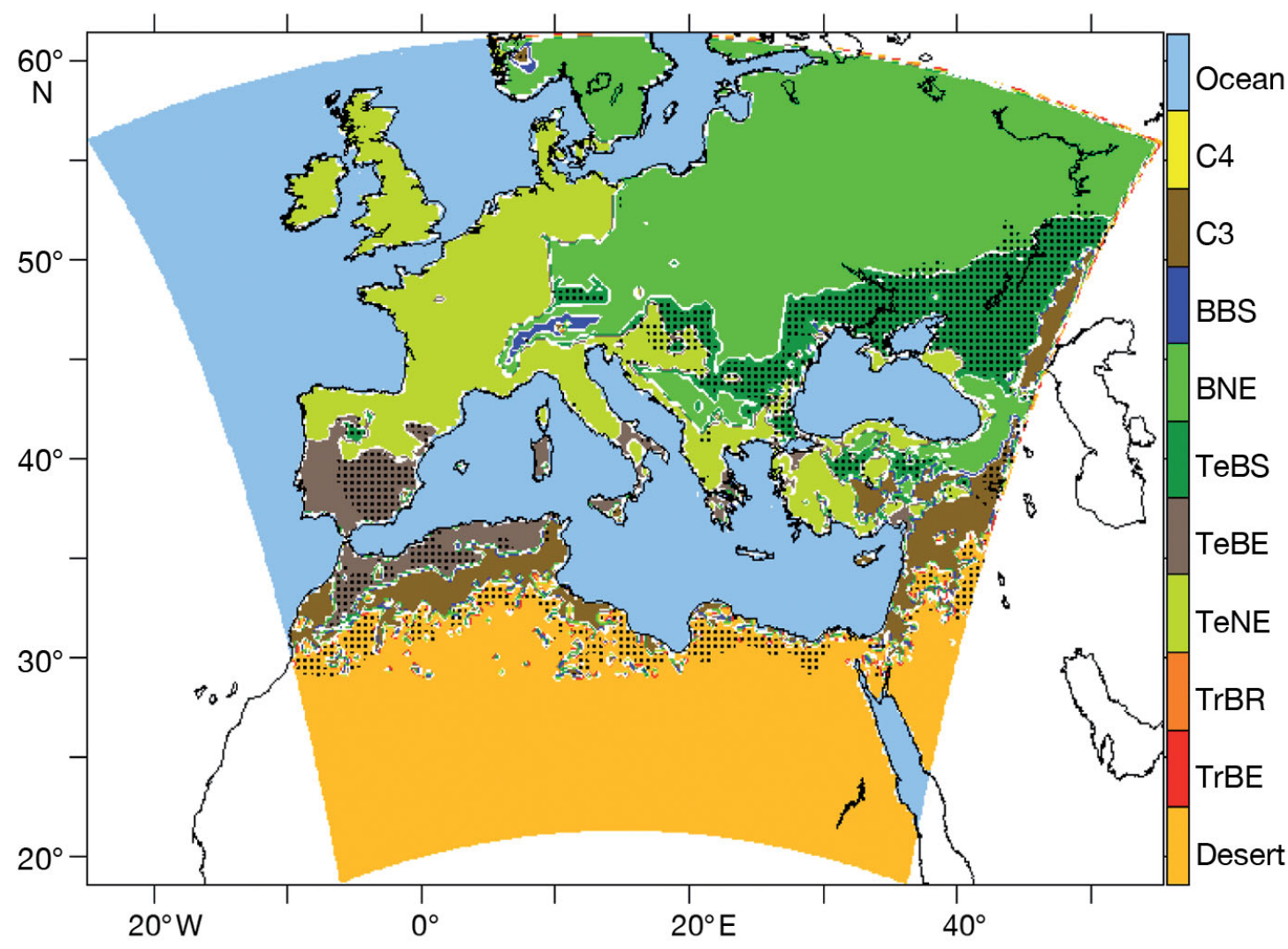

Fig. 8. Mean dominant PTFs coverage projected by the LPJ/PROTHEUS system for the period 2021-2050; black points indicate the areas where there is a change with respect to the mean cover of the temporal period 1961-1990 
Africa. As shown in Fig. 5, temperature increase and precipitation decrease lead to severe waterstress on vegetation. This new condition is unfavourable for any PFT, so instead of a transition from C3 toward C4 grass, we find desertification. The desertification in northern Africa is also favoured by an increase in fire frequency (Fig. 7) resulting from lower values in soil moisture related to the decreased precipitation.

Despite the reduction in precipitation and the increase in temperature in the coastal areas of NA and in Spain, temperate trees become the dominant PFT (Fig. 8). The substitution of grass with temperate trees leads to increasing water use efficiency, which improves the conditions for establishment of plants in this dry environment,
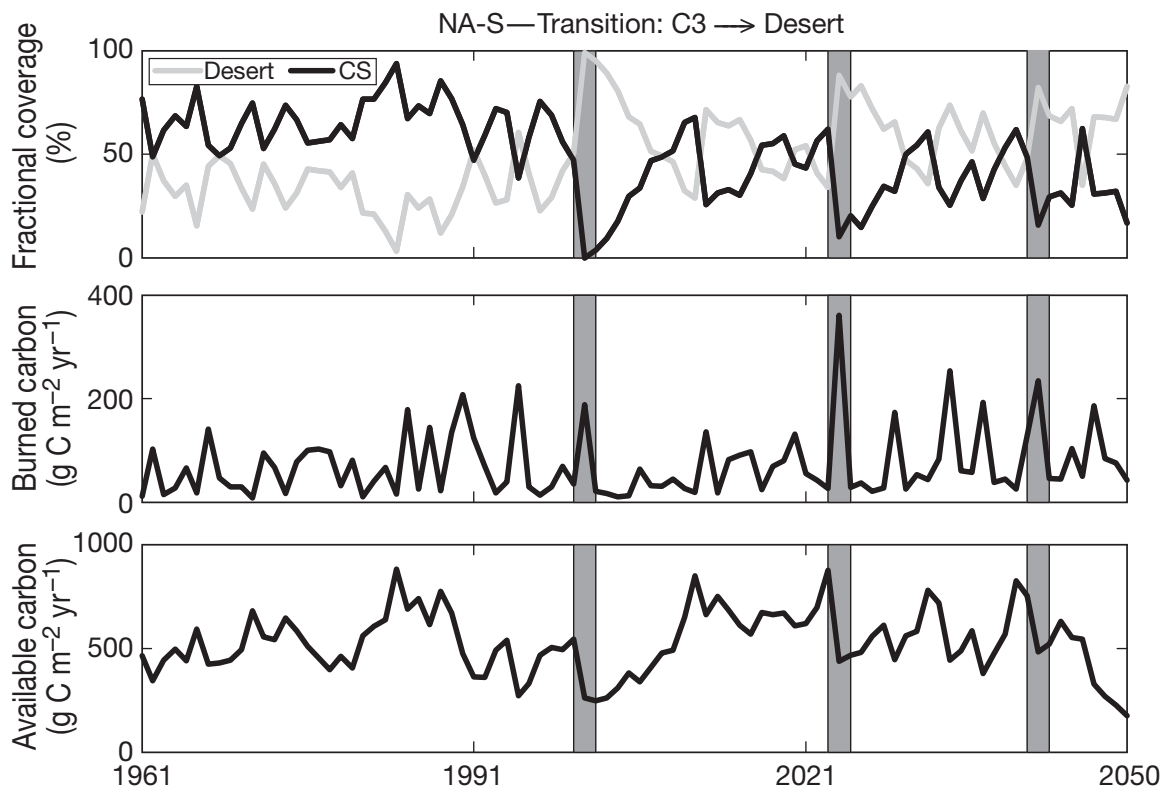

Fig. 9. Time series of vegetation distribution changes (top), burned carbon (middle) and available carbon for burning (vegetation + litter carbon, bottom) as simulated by LPJ for a small area (NA-S, see Fig. 1) inside the larger NA sub-domain. Shaded bands: fire events despite the severe summer water stress. A consequence of this extreme water stress in the Spanish forests during the dry season is that these forests are maintained with minimum activity from early spring to late autumn, when solar radiative flux is abundant and soil moisture is low, while the productive period is limited exclusively to the rainy season and a short period following the rain.

In order to understand how desert expansion takes place in NA, we focus on a smaller area inside the NA sub-domain (namely NA-S, see Fig. 1). The temporal series of dominant vegetation coverage, the available carbon for burning (vegetation + litter carbon), and the amount of burned carbon for NA-S are shown in Fig. 9. This figure demonstrates that all main vegetation changes result from severe fires. In this water-limited ecosystem, fire events are mainly due to a sequence of years with lower annual precipitation that lead to severe drought. In the model, when a fire event occurs, grid space is freed by reducing the fraction of the grid cell covered by $\mathrm{C} 3$ crops and increasing the amount of bare ground. Then, re-vegetation in NA is not favoured by the severe climatic conditions, explaining the progressive desertification that has taken place in this area. Fig. 9 also highlights how, during every fire event shown in the shaded bands, the available biomass is burned with a relevant reduction in terms of vegetation and soil carbon content.

Similarly, inside the MD sub-domain we select smaller MD-S domain (see Fig. 1) to explore the transition between grass and temperate evergreen trees.

Fig. 10 shows how this transition is favoured by a severe fire that takes place in the simulation (see shaded band) in the late 1980s. During this event, a relevant amount of available carbon is burned. After this fire, available carbon constantly increases according to the enhanced NPP (Fig. 7)

Finally, in the CE-S focus sub-domain (see Fig. 1), the transition between different PFT may be strongly related to rising temperatures, as suggested by the negative trend in BNE cover and by the positive trend in TeBS cover (Fig. 11). Likewise, BBS shows a negative trend, while temperate evergreen vegetation increases slowly until reaching $20 \%$ fractional coverage by 2050 . As in MD-S, an abrupt change in TeBS coverage for the CE-S focus sub-domain can also be related to a simulated severe fire event as shown by the shaded band in the 2030s; available carbon follows the expansion/decrease of TeBS. However, the main factor regulating vegetation transition in this area is temperature change.

\section{DISCUSSION AND CONCLUSIONS}

In our study we have explored potential changes in terrestrial carbon cycle and natural vegetation patterns over the Euro-Mediterranean region out to 2050 under the SRES A1B scenario using output from a high resolution fully coupled regional ocean-atmosphere model to force the LPJ dynamic vegetation model. Our results 

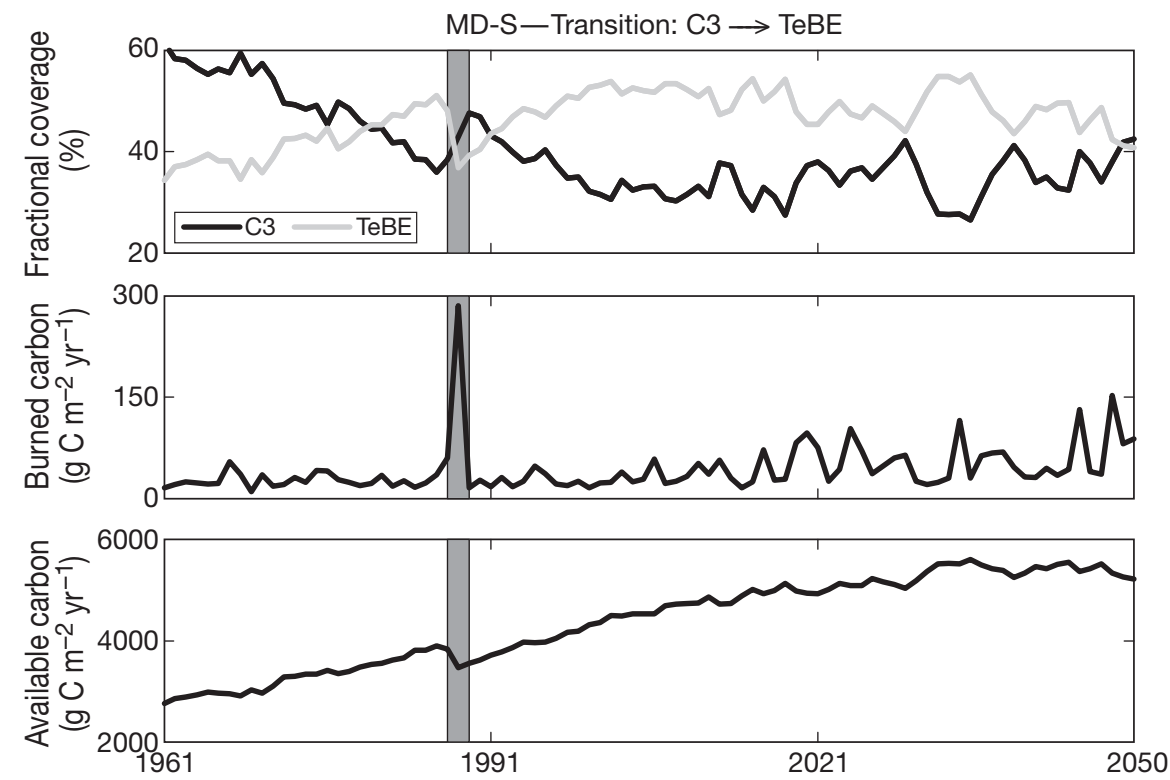

Fig. 10. Time series of vegetation distribution changes for the MD-S sub-domain. Other details as in Fig. 9
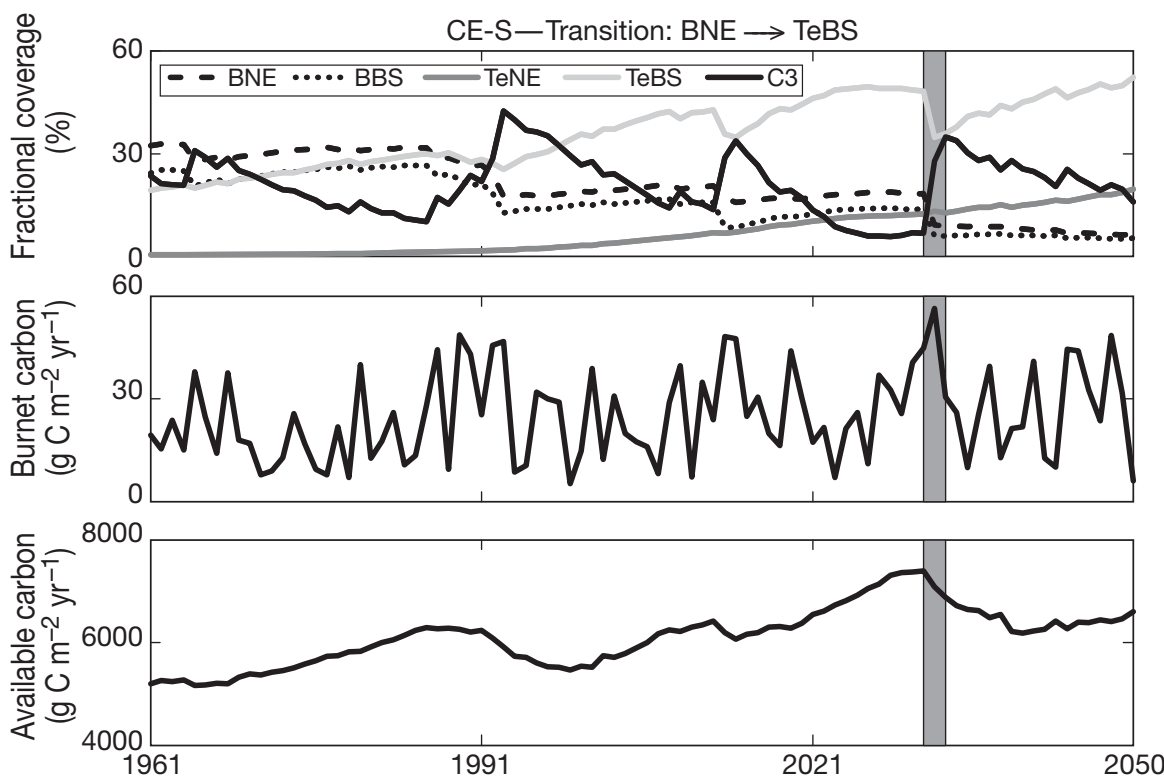

Fig. 11. Time series of vegetation distribution changes for the CE-S sub-domain. Other details as in Fig. 9

indicate that a future warmer climate will not only affect regional terrestrial carbon cycle, but can also significantly impact natural vegetation dynamics. Overall, European NPP may increase considerably under climate change $(+12 \%)$, as may also the carbon storage as vegetation biomass $(+20 \%)$, and the carbon losses from heterotrophic respiration $(+13 \%)$, while a weak increase in litter carbon $(+4 \%)$ may occur. The effects of climate warming are found to lead to an increase in fire occurrence over the whole domain. The amount of the carbon burned is about $24 \%$ more in the scenario than in the control simulation. The greater fire occurrence is found to be an important factor in regional vegetation dynamics.

A major finding of this study is that while major NPP increases are projected to occur mainly over parts of northern and central Europe, vegetation patterns in parts of southern Europe (Mediterranean and eastern Europe) and northern Africa could be most affected by changes in future climatic conditions. Specifically, in North Africa the severe drought projected for this area could make conditions too prohibitive for any PFTs, so instead of a replacement of $\mathrm{C} 3$ grass with C4 grass, there could be a transition to bare ground conditions (similar results were also found by Zeng \& Yoon 2009). In coastal North Africa and in Spain, temperate trees could become the dominant vegetation replacing grass. Finally, in eastern Europe, boreal vegetation and grass could be replaced by temperate deciduous trees as a consequence of higher temperatures and increased precipitation.

In each region, it is the combination of drought-resulting from increased temperature (in all sub-regions), reduced precipitation (in MD, NA) and increased fire occurrence-that is crucial in determining simulated vegetation dynamics and changes in patterns of dominant PFTs projected in our study.

Looking at the Mediterranean basin, our results agree with those from Gao \& Giorgi (2008). Specifically, they analyzed 3 different aridity indices finding that the southern areas of the Mediterranean, including most of the Iberian peninsulas, central and southern Italy, the Hellenic and Turkish peninsulas, the Middle East and northern Africa, are especially at risk of increased water stress on agriculture and natural ecosystems, and possibly desertification. 
Although our study does not directly explore scenario and model uncertainties, a number of considerations can be made to discuss the results above in light of model and scenario uncertainties. Temperature increase over the reference regions during the 19612050 period is generally less in the ECHAM/ PROTHEUS SRES projection than in most of the analyzed CMIP3 model projections. In addition, the PDSI decrease in the Mediterranean and North Africa regions is less than in the CMIP3 ensemble. Hence, it seems reasonable to conclude that the changes indicated by the LPJ projection driven by ECHAM/ PROTHEUS over these regions are not particularly extreme compared to what could have been obtained by using other CMIP3 simulations as lateral boundary forcing. On the other hand, PROTHEUS seems to exaggerate future precipitation increase over central Europe compared to the CMIP3 ensemble, so it is likely that related carbon cycle/vegetation changes simulated by PROTHEUS over this region will also be exaggerated. Additionally, as our experiments are based on the SRES A1B emission scenario (with intermediate emissions in relation to the other available scenarios) results are likely to be intermediate. Despite these considerations, it is clear that in view of the exploratory nature of our results, a full investigation of projected vegetation changes considering the full range of uncertainties is necessary. For instance, future investigations should consider uncertainties associated with the choice of the dynamic vegetation model and the downscaling technique, as well as changes in 'actual' vegetation cover versus those in 'natural' vegetation cover.

The natural vegetation changes highlighted in our study could have socio-economic effects, by impeding ecosystem services that benefit agriculture, forestry and other human activities, and, in turn, affecting the livelihood of people who depend on them. The desertification projected over parts of North Africa and associated land degradation will affect agriculture dramatically, by changing the geographical distribution of areas suited to different crops and animal rearing (see e.g. Desanker \& Justice 2001). This could also result in decreased crop yields and could raise poverty levels in affected countries (see e.g. Batterbury \& Warren 2001).

The land surface changes projected in this study could also have important feedbacks on climate which are currently not represented in CMIP3 and PROTHEUS model projections. In fact, both GCMs and RCMs generally make use of prescribed vegetation at the beginning of simulations rather than to grow the canopy and compute the leaf area index and vegetation dynamics as a function carbon allocation. This could be a serious limitation for transient climate simulations, since the vegetation may not be in equilibrium with the new climate (as we show, see Figs. 8-11). Specifically, via modifications of surface albedo, roughness length, leaf area index and rooting depth, land cover changes may affect climate by changing the partitioning of available energy between sensible and latent heat, and the partitioning of precipitation between evapotranspiration and runoff (Zhao et al. 2001). The strength of such effects on the modelled climate, however, depends on the general architecture and sensitivity of the atmospheric model that is used (Dumenil-Gates \& Ließ 2001).

In addition to vegetation cover changes, wild fires also have a direct impact on atmospheric chemistry and climate, with the emission of large quantities of aerosols (smoke) and trace gases, including large amounts of ozone precursors (Langmann et al. 2009).

Vegetation dynamics and carbon cycle changes, along with their climate feedbacks, should be investigated using Earth system models (fully coupled oceanatmosphere-land surface models, such as those which are being used in preparation for the next IPCC Assessment; Taylor et al. 2011) since they are better suited to account for shifts in vegetation and deforestation/desertification processes.

Acknowledgements. We acknowledge the PROTHEUS modeling group, the Program for Climate Model Diagnosis and Intercomparison and the WCRP's Working Group on Coupled Modeling for their roles in making available the WCRP CMIP3 multi-model dataset. This dataset is supported by the Office of Science, U.S. Department of Energy. We also acknowledge financial support by the EC IP CIRCE (Contract No. 036961).

\section{LITERATURE CITED}

Adcroft AJ, Hill CN, Marshall J (1997) Representation of topography by shaved cells in a height coordinate ocean model. Mon Weather Rev 125:2293-2315

Ainsworth E, Long S (2005) What have we learned from 15 years of free-air $\mathrm{CO}_{2}$ enrichment (FACE)? A meta-analytic review of the responses of photosynthesis, canopy properties and plant production to rising $\mathrm{CO}_{2}$. New Phytol 165: 351-372

Anav A, Ruti PM, Artale V, Valentini R (2010a) Modelling the effects of land cover-changes on surface climate in the Mediterranean region. Clim Res 41:91-104

> Anav A, D'Andrea F, Viovy N, Vuichard N (2010b) A validation of heat and carbon fluxes from high resolution land-surface and regional models. J Geophys Res 115: G04016

Artale V, Calmanti S, Carillo A, Dell'Aquila A and others (2009) An atmosphere-ocean regional climate model for the Mediterranean area: assessment of a present climate simulation. Clim Dyn 35:721-740

Batterbury S, Warren A (2001) The African Sahel 25 years after the great drought: assessing progress and moving towards new agendas and approaches. Glob Environ Change 11:1-8

Bonan G, Levis S, Sitch S, Vertenstein M, Oleson KW (2003) 
A dynamic global vegetation model for use with climate models: concepts and description of simulated vegetation dynamics. Glob Change Biol 9:1543-1566

Christensen JH, Christensen OB (2007) A summary of the PRUDENCE model projections of changes in European climate by the end of this century. Clim Change 81:7-30

> Cox PM, Betts RA, Jones CD, Spall SA, Totterdell IJ (2000) Acceleration of global warming due to carbon-cycle feedbacks in a coupled climate model. Nature 408:184-187

Cramer W, Bondeau A, Woodward FI, Prentice IC and others (2001) Global response of terrestrial ecosystem structure and function to $\mathrm{CO}_{2}$ and climate change: results from six dynamic global vegetation models. Glob Change Biol 7: 357-373

> Davidson EA, Janssens IA (2006) Temperature sensitivity of soil carbon decomposition and feedbacks to climate change. Nature 440:165-173

> Desanker P, Justice C (2001) Africa and global climate change: critical issues and suggestions for further research and integrated assessment modelling. Clim Res 17:93-103

Devi N, Hagedorn F, Moiseev P, Bugmann H, Shiyatov S, Mazepa V, Rigling A (2008) Expanding forests and changing growth forms of Siberian larch at the Polar Urals treeline during the 20th century. Glob Change Biol 14: 1581-1591

Dickinson RE, Henderson-Sellers A, Kennedy PJ (1993) Biosphere-Atmosphere Transfer Scheme (BATS) version $1 \mathrm{e}$ as coupled to the NCAR Community Climate Model. NCAR Technical note, NCAR/TN-387+STR, National Center for Atmospheric Research, Boulder, CO

Dumenil Gates L, Ließ S (2001) Impacts of deforestation and afforestation in the Mediterranean region as simulated by the MPI atmospheric GCM. Global Planet Change 30: 309-328

Findell KL, Shevliakova E, Milly PC, Stouffer RJ (2007) Modeled impact of anthropogenic land cover change on climate. J Clim 20:3621-3634

Gao X, Giorgi F (2008) Increased aridity in the Mediterranean region under greenhouse gas forcing estimated from high resolution simulations with a regional climate model. Global Planet Change 62:195-209

Gerber S, Joos F, Prentice IC (2004) Sensitivity of dynamic global vegetation model to climate and atmospheric $\mathrm{CO}_{2}$. Glob Change Biol 10:1223-1239

Gerten D, Schaphoff S, Lucht W (2007) Potential future changes in water limitations of the terrestrial biosphere. Clim Change 80:277-299

Giorgi F (1990) Simulation of regional climate using a limited area model nested in a general circulation model. J Clim 3:941-963

Giorgi F (2006) Climate change hot-spots. Geophys Res Lett 33:L08707

Giorgi F, Bi X (2005) Updated regional precipitation and temperature changes for the 21st century from ensembles of recent AOGCM simulations. Geophys Res Lett 32:L21715

Giorgi F, Mearns LO (1991) Approaches to regional climate change simulation: a review. Rev Geophys 29:191-216

Giorgi F, Mearns LO (1999) Introduction to special section: regional climate modeling revisited. J Geophys Res 104: 6335-6352

Giorgi F, Marinucci MR, Bates GT (1993a) Development of a second generation regional climate model (RegCM2). I. Boundary-layer and radiative transfer processes. Mon Weather Rev 121:2794-2813

Giorgi F, Marinucci MR, Bates GT, De Canio G (1993b) Development of a second generation regional climate model (RegCM2). II. Convective processes and assimilation of lateral boundary conditions. Mon Weather Rev 121: 2814-2832

Giorgi F, Bi X, Pal JS (2004) Mean, interannual variability and trends in a regional climate change experiment over Europe. I. Present-day climate (1961-1990). Clim Dyn 22: 733-756

Gullison RE, Frumhoff PC, Canadell JG, Field CB and others (2007) Tropical forests and climate policy. Science 316: 985-986

Heck P, Luthi D, Wernli H, Schar C (2001) Climate impacts of European-scale anthropogenic vegetation changes: a sensitivity study using a regional climate model. J Geophys Res 106:7817-7835

IPCC (Intergovernmental panel on climate change)(2001) Climate change 2001: the scientific basis. Cambridge University Press, Cambridge

Langmann B, Duncan B, Textor C, Trentmann J, Van Der Werf GR (2009) Vegetation fire emissions and their impact on air pollution and climate. Atmos Environ 43:107-116

Lucht W, Schaphoff S, Erbrecht T, Heyder U, Cramer W (2006) Terrestrial vegetation redistribution and carbon balance under climate change. Carbon Balance Manag $1: 1-7$

Mariotti A, Zeng N, Yoon JH, Artale V, Navarra A, Alpert P, Li L (2008) Mediterranean water cycle changes: transition to drier 21st century conditions in observations and CMIP3 simulations. Environ Res Lett 3:044001 doi:1088/17489326/3/4/044001

> Marshall J, Adcroft A, Hill C, Perelman L, Heisey C (1997a) A finite-volume, incompressible Navier Stokes model for studies of the ocean on parallel computers. J Geophys Res 102:5753-5766

Marshall J, Hill C, Perelman L, Adcroft A (1997b) Hydrostatic, quasi-hydrostatic, and nonhydrostatic ocean modelling. J Geophys Res 102:5733-5752

Meehl GA, Covey H, Delworth T, Latif M and others (2007) The WCRP CMIP3 multimodel dataset: a new era in climate change research. Bull Am Meteorol Soc 88: 1383-1394

Morales P, Hickler T, Rowell DP, Smith B, Sykes MT (2007) Changes in European ecosystem productivity and carbon balance driven by regional climate model output. Glob Change Biol 13:108-122

Nakicenovic N, Alcamo J, Davis C, de Vries B and others (2000) Emission scenarios. A special report of Working Group III of the Intergovernmental Panel on Climate Change. Cambridge University Press, Cambridge

New M, Hulme M, Jones PD (2000) Representing twentieth century space-time climate variability. II. Development of 1901-96 monthly grids of terrestrial surface climate. J Clim 13:2217-2238

> Notaro M, Liu Z, Vavrus S (2007) Global vegetation and climate change due to future increases in $\mathrm{CO}_{2}$ as projected by a fully coupled model with dynamic vegetation. J Clim 20:70-90

O'Brien K, Sygna L, Haugen JE (2004) Vulnerable or resilient? A multi-scale assessment of climate impacts and vulnerability in Norway. Clim Change 64:193-225

Pal JS, Small EE, Eltahir EAB (2000) Simulation of regional-scale water and energy budgets: representation of subgrid cloud and precipitation processes within RegCM. J Geophys Res 105:29579-29594

Pal JS, Giorgi F, Bi X, Elguindi N and others (2007) The ICTP RegCM3 and RegCNET: regional climate modeling for the developing world. Bull Am Meteorol Soc 88:1395-1409

Palmer WC (1965) Meteorological drought. Research Paper No. 45, US Department of Commerce Weather Bureau, 
Washington, DC

Qian H, Joseph R, Zeng N (2010) Enhanced terrestrial carbon uptake in the northern high latitudes in the 21st century from the Coupled Carbon Cycle Climate Model Intercomparison Project model projections. Glob Change Biol 16: 641-656

Reale O, Shukla J (2000) Modeling the effects of vegetation on Mediterranean climate during the Roman Classical Period. II. Model simulation. Global Planet Change 25: 185-214

Roeckner E, Bäuml G, Bonaventura L, Brokopf R and others (2003) The atmospheric general circulation model ECHAM5. I. model description. Max Planck Institute for Meteorology Rep. 349, MPI for Meteorology, Hamburg

Sanchez E, Gaertner MA, Gallardo C, Padorno E, Arribas A, Castro M (2007) Impacts of a change in vegetation description on simulated European summer present-day and future climates. Clim Dyn 29:319-332

Schaphoff S, Lucht W, Gerten D, Sitch S, Cramer W, Prentice IC (2006) Terrestrial biosphere carbon storage under alternative climate projections. Clim Change 74:97-122

Sheffield J, Wood EF (2008) Projected changes in drought occurrence under future global warming from multimodel, multi scenario, IPCC AR4 simulations. Clim Dyn 31:79-105

Sitch S, Smith B, Prentice IC, Arneth A and others (2003) Evaluation of ecosystem dynamics, plant geography and terrestrial carbon cycling in the LPJ dynamic global vegetation model. Glob Change Biol 9:161-185

Sitch S, Huntingford C, Gedney N, Levy PE and others (2008) Evaluation of the terrestrial carbon cycle, future plant geography and climate-carbon cycle feedbacks using five Dynamic Global Vegetation Models (DGVMs). Glob Change Biol 14:2015-2039

Editorial responsibility: Filippo Giorgi, Trieste, Italy
Taylor K, Stouffer RJ, Meehl GA (2011) A summary of the CMIP5 experiment design. 12th session of the JSC/ CLIVAR Working Group on Coupled Modelling, World Climate Research Programme (WCRP). Available at: http://cmip.llnl.gov/cmip5/docs/Taylor_CMIP5_design.pdf

> Thonicke K, Venevsky S, Sitch S, Cramer W (2008) The role of fire disturbance for global vegetation dynamics: coupling fire into a Dynamic Global Vegetation Model. Glob Ecol Biogeogr 10:661-677

Thonicke K, Spessa A, Prentice IC, Harrison SP, Dong L, Carmona-Moreno C (2010) The influence of vegetation, fire spread and fire behaviour on biomass burning and trace gas emissions: results from a process-based model. Biogeosciences Discuss 7:697-743

Tucker CJ, Slayback DA, Pinzon JE, Los SO, Myneni RB, Taylor MG (2001) Higher northern latitude normalized difference vegetation index and growing season trends from 1982 to 1999. Int J Biometeorol 45:184-190

Valentini R, Matteucci G, Dolman AJ and others (2000) Respiration as the main determinant of carbon balance in European forests. Nature 404:861-865

Zaehle S, Bondeau A, Carter TR, Cramer W and others (2007) Projected change in terrestrial carbon storage in Europe under climate and land use change. Ecosystems 10: 380-401

Zampieri M, Lionello P (2010) Simple statistical approach for computing land cover types and potential natural vegetation. Clim Res 41:205-220

> Zeng N, Yoon J (2009) Expansion of the world's deserts due to vegetation-albedo feedback under global warming. Geophys Res Lett 36:L17401. doi:10.1029/2009gl039699

- Zhao M, Pitman AJ, Chase T (2001) The impact of land cover change on the atmospheric circulation. Clim Dyn 17: 467-477

Submitted: June 28, 2010; Accepted: January 19, 2011

Proofs received from author(s): May14, 2011 